\title{
Measures of stimulus control and stimulus dominance
}

\author{
DONALD MELTZER and MARK A. MASAKI \\ Southern Illinois University, Carbondale, Ill. 62901
}

Six rats learned a discrimination in which they were reinforced for pressing Bar $A$ during a light, no-tone stimulus and for pressing Bar B during a tone, no-light stimulus. Five of the Ss responded at a higher mean rate on Bar B when neither light nor tone was present. All six Ss responded at a higher mean rate on Bar $A$ when both light and tone were present. The results were interpreted as demonstrating stimulus dominance in spite of the fact that both light and tone had gained control over behavior.

Many experiments have been performed in which Ss were required to discriminate between compound cue stimuli which differed along two different dimensions. In a number of these experiments, Ss learned to discriminate along only one of these dimensions and learned much less about the difference on the other dimension (e.g., Eckerman, 1967; Miles, 1965). In other compound cue discrimination experiments, Ss acquired a discrimination in which there were stimulus differences along two dimensions, and they learned more about one difference than the other, but the dimension along which an S would learn to respond differentially could not be predicted (e.g., Reynolds, 1961; Sutherland \& Holgate, 1966).

The dimension along which stimulus differences control the S's responses most effectively in compound cue discrimination experiments is often referred to as the more dominant or salient stimulus dimension (cf. Sutherland \& Mackintosh, 1971). Presumably, differences along this dimension are differentially responded to by the $S$ at the beginning of discrimination training and then maintain control of the behavior throughout the experiment. However, if the potential for stimulus dominance exists when there is as yet no stimulus control, there is no reason to assume that the potential for stimulus dominance has been eliminated when each stimulus has been presented separately and has gained some control over behavior. A demonstration of stimulus dominance under the latter conditions would require that each stimulus be presented equally often and that the probability of reinforcement during the presentation of each stimulus be the same. This experiment provides a demonstration of such stimulus dominance.

\section{METHOD}

\section{Subjects}

Six 90-day-old male hooded rats, bred in our laboratory, served as the Ss. Water was available to each $\mathrm{S}$ for $15 \mathrm{~min}$ after the session on weekdays and for $15 \mathrm{~min}$ at midday on the weekends. Food was always available to the Ss in their home cages. No food was ever present during the experimental session.

\section{Apparatus}

The Ss were run in a Lehigh Valley experimental chamber (Model 1316) with interior dimensions of $27.32 \times 30.48 \times$ $20.32 \mathrm{~cm}$. Two bars, each of which required approximately $20 \mathrm{~g}$ of pressure to operate, were located $2.86 \mathrm{~cm}$ above the floor and $3.80 \mathrm{~cm}$ from the side walls of the chamber. A liquid dipper that provided $0.06 \mathrm{cc}$ of water reinforcement was located at the base of the front wall midway between the sides. There were two pilot lights on the front wall of the chamber, located $5.72 \mathrm{~cm}$ above the floor and $3.49 \mathrm{~cm}$ from the side walls. Light intensity was measured with the light meter facing the front wall directly behind each bar. When both lights were on, illumination was $9.04 \mathrm{~mL} 2.54 \mathrm{~cm}$ behind both the left and right bars. The auditory stimulus was a $714-\mathrm{Hz}$ tone, which was $4 \mathrm{~dB}$ above a background noise level of $63 \mathrm{~dB}$.

Electromechanical control and recording equipment were in an adjoining room, and masking white noise was always present in the experimental room.

\section{Procedure}

Only the left bar was available in the chamber during the first 2 days of the experiment. On the first day, the light above the bar was on and the tone was off and the Ss were reinforced for each barpress. On the second day, the tone was on and the light was off and the Ss were reinforced each time they pressed the bar. The discrimination procedure began on the third day of the experiment. Two bars were available to the Ss. For three of the Ss, A1, A3, and A5, the left bar was designated "Bar A" and the right bar was designated "Bar B." For the other three Ss, A2, A4, and $A 6$, the right bar was designated "Bar $A$ " and the left bar, "Bar B." Responses on Bar A were reinforced on a variable interval (VI) 1-min schedule when the light was on and the tone was off. Responses on Bar B were never reinforced under these stimulus conditions. In both the light-on, tone-off $(S+)$ and the light-off, tone-on ( $\mathrm{S}+$ ) conditions, there was a 2 -sec changeover delay to minimize the probability that a response to the incorrect bar would be followed by a reinforced response on the correct bar. For instance, a response on Bar B during the light-on, tone-off $S+$ would be followed by 2 sec during which a response on Bar $A$ would never be reinforced. If there was a second response on Bar B during this 2-sec interval, the changeover delay would start again and no Bar A response would be reinforced for $2 \mathrm{sec}$ after the second Bar $B$ response. The stimulus conditions did not change during the changeover delay. There were 10 presentations of each stimulus condition during the sessions, and each stimulus presentation lasted for $2 \mathrm{~min}$. The order of presentation of the stimuli was changed every third day.

Between each 2-min stimulus presentation, there was an interval during which both the tone and the light were turned off. No responses were reinforced when both tone and light were absent, and this (S-) condition lasted until $15 \mathrm{sec}$ had passed without the $S$ making a response on either bar. The 15-sec no-response requirement was selected because other experiments in our laboratory had shown that, with this short an interval, rats would respond at a moderate rate during $S$ - rather than at an extremely low rate. There were a total of 40 sessions using this procedure.

For the next 12 sessions, a test interval procedure was used. There were only eight presentations of each S+. However, there were also three 2-min test intervals during which no responses were reinforced. The first test interval was not presented until each $S+$ had been presented at least once. In one of the test intervals, the light was on and the tone was off; in another, the tone was on and thylight was off; and in the third test interval, both the light and tone were on. The time within the sessions at 
Table 1

Mean Response Rates (Responses/Minute) and Standard Deviations (SD) During the Light No-Tone S+, the Tone, No-Light $\mathrm{S}+$, and the No-Tone, No-Light $\mathrm{S}-$ Conditions

\begin{tabular}{|c|c|c|c|c|c|c|c|}
\hline \multirow[b]{2}{*}{ Ss } & & \multicolumn{2}{|c|}{$\begin{array}{c}\text { S+ } \\
\text { Light, } \\
\text { No-Tone } \\
\end{array}$} & \multicolumn{2}{|c|}{$\begin{array}{c}\text { S+ } \\
\text { Tone, } \\
\text { No-Light }\end{array}$} & \multicolumn{2}{|c|}{$\begin{array}{c}\text { S- } \\
\text { No-Tone, } \\
\text { No-Light }\end{array}$} \\
\hline & & Bar A & Bar B & Bar A & Bar B & Bar A & Bar B \\
\hline A1 & $\begin{array}{l}\text { Mean } \\
\text { SD }\end{array}$ & $\begin{array}{r}11.83 \\
2.73\end{array}$ & $\begin{array}{l}1.35 \\
0.87\end{array}$ & $\begin{array}{l}1.03 \\
0.81\end{array}$ & $\begin{array}{r}11.24 \\
2.57\end{array}$ & $\begin{array}{l}2.48 \\
1.90\end{array}$ & $\begin{array}{l}5.89 \\
3.87\end{array}$ \\
\hline A2 & $\begin{array}{l}\text { Mean } \\
\text { SD }\end{array}$ & $\begin{array}{l}9.02 \\
1.31\end{array}$ & $\begin{array}{l}1.25 \\
1.14\end{array}$ & $\begin{array}{l}0.67 \\
0.48\end{array}$ & $\begin{array}{c}14.4 \\
3.24\end{array}$ & $\begin{array}{l}1.47 \\
0.64\end{array}$ & $\begin{array}{l}6.01 \\
2.02\end{array}$ \\
\hline A3 & $\begin{array}{l}\text { Mean } \\
\text { SD }\end{array}$ & $\begin{array}{r}15.08 \\
2.75\end{array}$ & $\begin{array}{l}0.48 \\
0.29\end{array}$ & $\begin{array}{l}1.21 \\
1.17\end{array}$ & $\begin{array}{l}9.97 \\
2.16\end{array}$ & $\begin{array}{l}4.16 \\
3.09\end{array}$ & $\begin{array}{l}3.86 \\
2.40\end{array}$ \\
\hline A4 & $\begin{array}{l}\text { Mean } \\
\text { SD }\end{array}$ & $\begin{array}{r}18.21 \\
6.25\end{array}$ & $\begin{array}{l}0.99 \\
0.47\end{array}$ & $\begin{array}{l}1.34 \\
0.76\end{array}$ & $\begin{array}{r}13.63 \\
4.03\end{array}$ & $\begin{array}{l}4.26 \\
1.86\end{array}$ & $\begin{array}{l}6.54 \\
3.01\end{array}$ \\
\hline A5 & $\begin{array}{l}\text { Mean } \\
\text { SD }\end{array}$ & $\begin{array}{l}6.18 \\
0.94\end{array}$ & $\begin{array}{l}1.99 \\
0.67\end{array}$ & $\begin{array}{l}1.16 \\
0.66\end{array}$ & $\begin{array}{l}9.69 \\
1.52\end{array}$ & $\begin{array}{l}1.67 \\
0.60\end{array}$ & $\begin{array}{l}5.48 \\
1.46\end{array}$ \\
\hline A6 & $\begin{array}{l}\text { Mean } \\
\text { SD }\end{array}$ & $\begin{array}{r}17.33 \\
6.98 \\
\end{array}$ & $\begin{array}{l}0.88 \\
0.89\end{array}$ & $\begin{array}{l}1.67 \\
2.45\end{array}$ & $\begin{array}{r}12.67 \\
5.62\end{array}$ & $\begin{array}{l}2.20 \\
1.34\end{array}$ & $\begin{array}{l}4.54 \\
1.08\end{array}$ \\
\hline
\end{tabular}

Table 2

Mean Ratios of $\mathrm{S}+/ \mathrm{S}-$ Response Rates on the Same Bar

\begin{tabular}{llc}
\hline S & Bar A & Bar B \\
\hline A1 & 4.77 & 1.91 \\
A2 & 6.14 & 2.40 \\
A3 & 3.63 & 2.58 \\
A4 & 4.27 & 2.08 \\
A5 & 3.70 & 1.77 \\
A6 & 7.88 & 2.80 \\
\hline
\end{tabular}

Table 3

Mean Response Rates (Responses/Minute) and Standard Deviations (SD) During the Light, No-Tone Test Interval, the Tone, No-Light Test Interval, and the Light + Tone Test Interval

\begin{tabular}{|c|c|c|c|c|c|c|c|}
\hline \multirow[b]{2}{*}{ Ss } & & \multicolumn{2}{|c|}{$\begin{array}{c}\text { Light, } \\
\text { No-Tone } \\
\end{array}$} & \multicolumn{2}{|c|}{$\begin{array}{c}\text { Tone, } \\
\text { No-Light }\end{array}$} & \multicolumn{2}{|c|}{$\begin{array}{c}\text { Light } \\
+ \text { Tone } \\
\end{array}$} \\
\hline & & Bar A & Bar B & Bar A & Bar B & Bar A & Bar B \\
\hline A1 & $\begin{array}{l}\text { Mean } \\
\text { SD }\end{array}$ & $\begin{array}{r}17.71 \\
9.13\end{array}$ & $\begin{array}{l}1.92 \\
1.51\end{array}$ & $\begin{array}{l}0.21 \\
0.33\end{array}$ & $\begin{array}{r}24.04 \\
6.67\end{array}$ & $\begin{array}{r}24.42 \\
8.94\end{array}$ & $\begin{array}{l}7.13 \\
5.41\end{array}$ \\
\hline A2 & $\begin{array}{l}\text { Mean } \\
\text { SD }\end{array}$ & $\begin{array}{r}11.88 \\
5.10\end{array}$ & $\begin{array}{l}2.04 \\
5.00\end{array}$ & $\begin{array}{l}0.54 \\
0.93\end{array}$ & $\begin{array}{r}14.17 \\
2.72\end{array}$ & $\begin{array}{r}11.75 \\
7.44\end{array}$ & $\begin{array}{l}7.37 \\
3.99\end{array}$ \\
\hline A3 & $\begin{array}{l}\text { Mean } \\
\text { SD }\end{array}$ & $\begin{array}{r}20.58 \\
9.34\end{array}$ & $\begin{array}{l}0.63 \\
0.74\end{array}$ & $\begin{array}{l}0.88 \\
0.32\end{array}$ & $\begin{array}{r}11.17 \\
5.62\end{array}$ & $\begin{array}{r}19.08 \\
8.51\end{array}$ & $\begin{array}{l}1.71 \\
1.60\end{array}$ \\
\hline A4 & $\begin{array}{l}\text { Mean } \\
\text { SD }\end{array}$ & $\begin{array}{r}21.79 \\
8.78\end{array}$ & $\begin{array}{l}1.42 \\
1.19\end{array}$ & $\begin{array}{l}3.00 \\
3.42\end{array}$ & $\begin{array}{r}14.67 \\
6.83\end{array}$ & $\begin{array}{r}24.63 \\
9.13\end{array}$ & $\begin{array}{l}3.17 \\
2.61\end{array}$ \\
\hline A5 & $\begin{array}{l}\text { Mean } \\
\text { SD }\end{array}$ & $\begin{array}{l}9.88 \\
4.98\end{array}$ & $\begin{array}{l}4.00 \\
3.31\end{array}$ & $\begin{array}{l}1.75 \\
2.50\end{array}$ & $\begin{array}{r}10.79 \\
4.15\end{array}$ & $\begin{array}{r}11.21 \\
4.48\end{array}$ & $\begin{array}{l}5.42 \\
2.77\end{array}$ \\
\hline A6 & $\begin{array}{l}\text { Mean } \\
\text { SD }\end{array}$ & $\begin{array}{r}17.33 \\
6.98\end{array}$ & $\begin{array}{l}0.88 \\
0.89\end{array}$ & $\begin{array}{l}1.67 \\
2.45\end{array}$ & $\begin{array}{r}12.67 \\
5.62\end{array}$ & $\begin{array}{r}16.38 \\
5.46\end{array}$ & $\begin{array}{l}3.50 \\
1.72\end{array}$ \\
\hline
\end{tabular}

which the test intervals were presented was changed every day. There was always an $\mathrm{S}$ - presentation before and after each test interval, and two test intervals were not presented without at least two $\mathrm{S}+\mathrm{s}$ being presented between them.

\section{RESULTS}

Table 1 shows the mean response rate of each $\mathrm{S}$ on both bars during each $\mathrm{S}+$ and during $\mathrm{S}-$ for the 12 sessions during which test intervals were presented.
There are several indices of stimulus control available in these data. If response rate during $\mathrm{S}+$ is examined, it is clear that all the Ss respond at much higher rates on the correct bar (i.e., Bar $\mathrm{A}$ in the light, no-tone condition and $\mathrm{Bar} B$ in the tone, no-light condition) than on the incorrect bar. In fact, the highest rate at which any $S$ ever responded on the incorrect bar in any session never reached the lowest rate at which any $S$ ever responded on the correct bar in any session. It is also clear that although some Ss (A1, A3, A4, and A6) responded at a higher mean rate on Bar $\mathbf{A}$ when it was correct as compared to their response rates on Bar B when it was correct, other Ss (A2 and A5) showed the opposite effect. The difference between mean S+ response rates on Bar A and Bar B was not statistically significant. When the results were considered in terms of response rates on the left bar when it was correct as compared to response rates on the right bar when it was correct, it was seen that the specific bar was not related to whether response rates were highest on Bar A or Bar B. If the criterion of stimulus control is response rate during the presentation of $\mathrm{S}+$, it must be concluded that there was no consistent difference in stimulus control.

Examination of the response rate of each $S$ during $S$ presentation reveals that five of the six Ss responded at a higher mean rate on Bar B than on Bar A during $\mathrm{S}-$, and a two-tailed $t$ test showed this difference to be significant $(t=3.87, \mathrm{df}=5, \mathrm{p}<.02)$. The effect was very reliable in the five Ss that demonstrated it: A2, A5, and $A 6$ responded at a higher rate on Bar $B$ than on Bar $A$ in all 12 sessions, and $A 1$ and $A 4$ responded at a higher rate on Bar B in 10 of the 12 sessions. Even A3, that had a slightly higher mean response rate on Bar A, actually responded at a higher rate on Bar B in 7 of the 12 sessions.

The data in Table 1 also were considered in the form of the ratio of mean $S+$ response rate to mean $S$ response rate on each bar, and these ratios are presented in Table 2. To calculate these ratios, the mean response rate on Bar A during the light, no-tone S+ was divided by mean response rate on the same bar during the no-tone, no-light $\mathrm{S}-$. Mean response rate on Bar B during tone, no-light was divided by mean response rate on the same bar during the no-tone, no-light $\mathrm{S}-$. All six Ss had higher ratios on Bar A than on Bar B, and the difference between the ratios was significant $(t=5.24$, $\mathrm{df}=5, \mathrm{p}<.005)$.

The test interval response rates shown in Table 3 indicate that stimulus control was effective even when no reinforcements were delivered. All six Ss had higher mean response rates on Bar A than on Bar B during the light, no-tone test interval, and all six Ss had higher rates on Bar B during the tone, no-light test interval. For four of the Ss, there was never any instance in which response rate on the incorrect bar was higher than response rate on the correct bar during these test intervals. A2 and A5 each had higher rates on the incorrect bar during one test interval presentation. As was true during 
presentation of the Sts, three Ss had higher response rates on Bar A during the light, no-tone test interval than on Bar B during the tone, no-light test interval. For the other Ss, the reverse was true. The difference between mean correct response rates on Bar A and Bar B during the test intervals was not significant. In the test interval during which both light and tone were presented, all six Ss responded at a higher mean rate on Bar A than on Bar B. The difference between mean response rates on the two bars was significant $(t=4.73, \mathrm{df}=5, \mathrm{p}<.005)$ and the effect was quite consistent. A3, A4, and A6 responded at a higher rate on $B$ ar $A$ in all 12 presentations of the light + tone test interval, A1 and A5 in 11 of the 12 light + tone test intervals, and A2 in 7 of the 12 light + tone test intervals.

\section{DISCUSSION}

A comparison of the response rates on the correct bar during each $\mathrm{S}+$ would not have led one to predict that there would be consistent differences between response rates on $B a r A$ and Bar B when S- was present or when both $\mathrm{S}+\mathrm{s}$ were present. However, such differences did appear even though the two $S+s$ did not produce significant differences in response rate. The ratio of $\mathrm{S}+/ \mathrm{S}$ - response rate was higher on Bar A than on Bar B, which suggests that there were differences in stimulus control of responses on the two bars. It could be argued that such differences in stimulus control could best be understood by the use of preference tests such as the one used in this experiment. When neither $S+$ is present and the $S$ continues to respond, it is in such a preference test situation. In that case, it will presumably respond at a higher rate on the bar on which stimulus control is weaker. When both $S+s$ are present, the $S$ will respond at a higher rate on the bar on which responses are under stronger stimulus control. By these standards, light appeared to exert much greater control over behavior in this experiment than did tone.

\section{REFERENCES}

Eckerman, D. A. Stimulus control by part of a complex $S \Delta$. Psychonomic Science, 1967, 7, 299-300

Miles, C. G. Acquisition of control by the features of a compound stimulus in discriminative operant conditioning. Unpublished doctoral dissertation, McMaster University, 1965. Cited by Sutherland, N. S., \& Mackintosh, N. J., in Mechanisms of animal discrimination learning. New York: Academic Press, 1971.

Reynolds, G. S. Attention in the pigeon. Journal of the Experimental Analysis of Behavior, 1961, 4, 203-208.

Sutherland, N. S., \& Holgate, V. Two-cue discrimination learning in rats. Journal of Comparative \& Physiological Psychology, 1966, 61, 198-207.

Sutherland, N. S., \& Mackintosh, N. J. Mechanisms of animal discrimination learning. New York: A cademic Press, 1971.

(Received for publication August 30, 1972.) 